\title{
Cmentarz wczoraj i dziś. Zmiany w funkcjonowaniu cmentarzy w opiniach trzech pokoleń mieszkańców wsi polskiej (na przykładzie Smardzowa)
}

\author{
DOI: 10.19195/2083-7763.8.15
}

\section{Wstęp}

Na cmentarz można spojrzeć jako na „tekst kultury”, który obrazuje znamienny dla danej epoki stosunek do śmierci, a zarazem stosunek do życia. Niejednokrotnie cmentarze więcej mówią o żyjących, którzy stawiają nagrobki i odbywają rytuały kultu zmarłych, niż o tych, którzy zostali pochowani ${ }^{1}$. Rytuał pogrzebu oraz późniejsze praktyki upamiętniające zmarłego wzmacniają więzi rodzinne, krewniacze. Cmentarz jest specyficzną przestrzenią, w której buduje się wspólnotę tych, którzy już zeszli z tego świata, oraz wspólnotę żyjących, będących przecież „przyszłymi umarłymi”. Cmentarz jest miejscem, w którym możliwe jest podtrzymywanie i wzmacnianie istniejących więzi społecznych

W sensie administracyjno-prawnym cmentarz to wyraźnie wyodrębniony, oznaczony i delimitowany teren przeznaczony do grzebania zmarłych, mogiły są na nim wyraźnie wyodrębnione w „Zwyczajowo przyjętej formie wizualnej”2. Kształtem mogił rządzą zwyczaj i tradycja. Każdy grób jest wyrazem indywidualności człowieka, jego życia i ostatecznego przeznaczenia. Roch Sulima pisze, iż grób, nagrobek, napis jakby równoważy i zastępuje emocjonalną oraz społeczną przestrzeń zmaterializowaną kiedyś wokół zmarłego, symbolizuje człowieka ${ }^{3}$.

Grób i cmentarz w życiu społecznym mogą pełnić funkcje przestrzeni intymnej. Mamy „swoje” groby i „swoje” cmentarze. Cmentarze są tymi szczególnymi

1 J. Kolbuszewski, Cmentarze, Wrocław 1996, s. 30-31.

2 Ibidem, s. 33.

3 R. Sulima, Stowo i etos, Kraków 1992. 
miejscami, które legitymizują prawo własności danej grupy (szerzej - zbiorowości etnicznej, narodu) do określonej ziemi. Niewątpliwie groby i emocjonalny charakter, który przypisuje się im, „uznając za własne”, są jednym z ważniejszych czynników wpływających na przywiązanie jednostki do określonego terytorium (do wykształcenia poczucia bycia u siebie).

Cmentarz jest specyficzną przestrzenią pamięci, którą można opisać przez dwa różne wymiary. Przebywanie na cmentarzu, poza złożeniem kwiatów, zapaleniem świeczki, sprzątnięciem spadłych na mogiłę liści, jest okazją do przypomnienia sobie wspólnych chwil spędzonych $\mathrm{z}$ daną osobą, opowieści o niej. Poza tym cmentarze - szczególnie wiejskie, na których grobów obcych osób, spoza społeczności, jest niewiele - są miejscem podtrzymywania pamięci o danej społeczności lokalnej.

Funkcjonowanie cmentarza jest w pewnym senesie odzwierciedleniem społeczności, do której należy, jest wskazaniem wartości przez nią kultywowanych, czytelnym zapisem zjawisk społecznych i kulturowych ${ }^{4}$.

Celem artykułu jest przedstawienie zmian, jakie zaszły w funkcjonowaniu cmentarzy i w praktykach upamiętniania zmarłych w opiniach trzech pokoleń mieszkanek wsi Smardzów. Dzięki takiemu doborowi respondentów podjęta zostanie próba pokazania przekształceń, jakie dokonały się w tym zakresie w ciągu ostatnich kilkudziesięciu lat.

Badania zostały przeprowadzone wśród mieszkańców Smardzowa w maju i czerwcu 2008 roku. Jest to wioska licząca 402 osoby, znajduje się około 20 kilometrów na północny wschód od Wrocławia. Przybyli po II wojnie światowej mieszkańcy pochodzili z różnych stron Polski, nie jest to więc ludność w całości przesiedlona $\mathrm{z}$ jednej wioski, jak to ma miejsce w przypadku innych miejscowości. Kościół został wybudowany 32 lata temu, ksiądz nie podjął decyzji o założeniu cmentarza, dlatego większość zmarłych jest pochowana w odległej o 4 kilometry Oleśnicy. Ważne jest podkreślenie, że procesy suburbanizacji następują w badanej miejscowości relatywnie szybciej niż w innych wsiach. Ze względu na niedużą odległość od miasta wojewódzkiego oraz miasta gminnego zmiany we wzorach i praktykach dotyczących organizacji przestrzeni cmentarnej również następowały szybciej.

Dobór próby był nielosowy, zastosowano tzw. metodę kuli śnieżnej. W zamierzeniu miały to być panie o pogłębionej wiedzy na temat zwyczajów towarzyszących pogrzebowi oraz funkcjonowania cmentarzy. Respondentki najstarsze oraz w średnim wieku łączy uczestnictwo w Zgromadzeniu Matek Różańcowych, jedynej organizacji, która oprócz rady parafialnej i ministrantów działa przy kościele.

Przeprowadzonych zostało dwanaście wywiadów, po cztery w trzech grupach wiekowych. Pierwszą grupę stanowiły starsze panie, tzn. po 65. roku życia, które pamiętają jeszcze czasy, gdy nie mieszkały w Smardzowie. Pierwsi mieszkańcy

${ }^{4}$ J. Straczuk, Cmentarz i stót, Toruń 2013, s. 166. 
wsi w większości pochodzili z Polski Centralnej - okolic Tarnowa, Rzeszowa oraz z Kresów Wschodnich - okolic Lwowa. Wszystkie respondentki z tej grupy całe życie przepracowały na roli, dwie panie pracowały też w fabryce znajdującej się na wsi. Edukację zakończyły na szkole podstawowej.

Następnie zostały przeprowadzone wywiady z repondentkami w wieku 40-50 lat, które urodziły się już w Smardzowie i spędziły tu całe życie. Wszystkie panie założyły rodziny, dwie pracują zawodowo - mają wykształcenie wyższe i średnie, dwie żyją z gospodarstwa rolnego - pierwsza z nich ma wykształcenie średnie, a druga - zawodowe.

Ostatnią grupę respondentek stanowiły osoby w wieku 20-30 lat. Dwie z nich są mężatkami, jedna ma dwoje dzieci i wykształcenie zawodowe, druga — jedno dziecko i wykształcenie wyższe. Dwie najmłodsze respondentki są w trakcie studiów, jedna dodatkowo pracuje zawodowo. Wszystkie są wierzące i praktykujące. Osoby w średnim i młodszym wieku raz w tygodniu uczestniczą w niedzielnej mszy świętej, najstarsze panie biorą udział w mszy kilka razy w tygodniu.

Na początku nowo przybyli mieszkańcy Smardzowa w większości zajmowali się tylko rolnictwem. Wszystkie respondentki pochodzą z rodzin rolniczych; należy jednak dodać, że obecnie na wsi tylko kilka rodzin wskazuje dochody z gospodarstwa rolnego jako główne źródło utrzymania. Około jedna trzecia mieszkańców przeprowadziła się do Smardzowa w ciągu ostatnich piętnastu lat.

Badania zostały przeprowadzone metodą jakościową. Techniką badawczą zastosowaną w celu zebrania informacji był wywiad ze standaryzowaną listą pytań, natomiast narzędziem badawczym - samodzielnie skonstruowany kwestionariusz wywiadu o mniejszym stopniu standaryzacji ${ }^{5}$. Przeprowadzone wywiady miały na celu skłonienie rozmówcy do zastosowania własnych pojęć, ujęcie tych pojęć $\mathrm{w}$ ich kontekście, rozszerzenie lub skracanie odpowiedzi na pewne pytania ${ }^{6}$. Dzięki tej technice unika się schematyzacji oraz narzucania badanym odpowiedzi. Szczególnie cenna okazała się ona w rozmowie z osobami z najstarszej kategorii wiekowej.

\section{Cmentarz - miejsce znaczące}

Cmentarz jest miejscem szczególnym, zorganizowanym na zasadzie określonej wyraźnie celowości, jest miejscem sakralizacji śmierci. W średniowieczu prawnie nakazano ich ogradzanie, aby symbolicznie oddzielić sferę sacrum od profanum. Koncepcję cmentarza jako przestrzeni nienaruszalnej i świętej wczesne chrześcijaństwo przejęło z tradycji rzymskiej. Cmentarze jako miejsca święte chronione

${ }^{5}$ I. Przybyłowska, Wywiad swobodny ze standaryzowana lista poszukiwanych informacji i możliwości jego zastosowania w badaniach socjologicznych, „Przegląd Socjologiczny” 30, 1978, s. 63.

6 I. Helling, Metoda badań biograficznych, [w:] Metoda biograficzna w socjologii, red. J. Włodarek, M. Ziółkowski, Warszawa 1990, s. 23. 
były specjalnymi immunitetami, obejmowały one także prawo azylu. Sobór rzymski w 1059 roku nadał im sankcję „pól świętych”, rzucając klątwę na bezczeszczących je. Synod sieradzki w 1233 roku groził ekskomuniką za znieważanie cmentarzy; synod włodawski w 1586 roku zabronił wypasu bydła na nich, synod warmiński w 1620 roku zakazał suszenia na nich bielizny, zaś synod kijowski jeszcze w 1762 roku oponował przeciwko odbywaniu targów na cmentarzach ${ }^{7}$.

Cmentarze nie raz spełniały liczne funkcje wtórne, które byłe sprzeczne z ich podstawową rolą. Na takich zasadach bywały miejscem jarmarków i zabaw, następnie sądów i sejmików, procesji i kazań. Nieraz wykonywano na nich kary świeckie, łącznie $\mathrm{z}$ egzekucjami. Lud odbywał tu także nieakceptowane przez kościół praktyki religijne (np. obrzędy dziadów); były one miejscami manifestacji politycznych, a nawet zbiórek partyzanckich. Niekiedy inne funkcje użytkowe nadawano cmentarzom świadomie, na przykład obudowując mocnym murem i wyposażając w okienka strzelnic dawne cmentarze typu obronnego.

Istnieje wiele różnych rodzajów cmentarzy. Najbardziej podstawowy podział, jakiego można dokonać, to wyróżnienie typów wyznaniowych i świeckich. Organizacja przestrzeni i formy ekspresji na tych pierwszych są podporządkowane zasadom wiary danej religii ${ }^{8}$. Kolejnym kryterium podziału może być porządek instytucjonalno-funkcjonalny. To kryterium pozwala wyodrębnić cmentarze wedle okoliczności ich powstania, jak i grupy osób na nich pochowanych. Wyróżniamy tu: zakonne cmentarze przyklasztorne, nieliczne $\mathrm{w}$ Polsce cmentarze prywatne, cmentarze wojenne i wojskowe. Bardzo popularne do końca XVIII wieku były cmentarze szpitalne, następnie cmentarze zamkowe, cmentarze skazańców (grzebanych poza bramami miast, nie robiono im grobów, nie stawiano krzyży), cmentarze więzienne i epidemiczne. Bardzo ważną rolę pełnią cmentarze osób zasłużonych - zalicza się do nich cmentarz na Powązkach w Warszawie, cmentarz Rakowiecki w Krakowie, stary cmentarz w Zakopanem na Pęksowym Brzyzku9.

Istotna jest lokalizacja cmentarza. Wyróżniamy tu cmentarze miejskie i wiejskie. Istnieją cmentarze górskie, leśne i ogrodowe. Czasem cmentarze były świadomie zakładane poza miejscowością w celu osiągnięcia odpowiednich efektów wizualnych, estetycznych ${ }^{10}$.

Kolejny ważny (z punktu widzenia historii sztuki) system klasyfikacji cmentarzy to założony typ ich organizacji, który zawsze miał na celu ich upiększenie. Pierwszy z nich wywodzi się z Włoch - są to wirydarzowe cmentarze typu Campo Santo (Pole Święte). Na przełomie XVIII i XIX wieku wprowadzono

7 J. Kolbuszewski, op. cit., s. 42.

8 A. Sobczak, Poradnik cmentarny. Kościelne i cywilne normy prawne o cmentarzach i chowaniu zmarlych wraz z orzecznictwem, Gniezno 2003.

9 A. Olej-Kobus, K. Kobus, M. Rembas, Nekropolie. Zabytkowe cmentarze wielokulturowej Polski, Warszawa 2009.

10 A. Jaszczak, B. Dreksler, Cmentarze - miejsca pamięci, tradycji i religii, [w:] Cmentarze i ogrody w krajobrazie. O sacrum, symbolice, kompozycji i przemijaniu, red. A. Zachariasz, Sosnowiec 2013. 
cmentarze oparte na założeniach ogrodowych i parkowych. Arnold Toynbee twierdzi, że stały się one harmonijnym połączeniem reminiscencji Pól Elizejskich, Wysp Szczęśliwych, „wszechogarniającego łona przyrody” i „miłosiernej matki-ziemi" - były miejscem medytacji, refleksji. Starano się unikać geometrycznego układu ścieżek i kwater. Na tych założeniach były oparte cmentarz wileński $\mathrm{Na}$ Rossie, Cmentarz Łyczakowski, Cmentarz Rakowicki. Przeciwstawnym typem są cmentarze-miasta umarłych, które pojawiły się w wyniku intensywnych procesów urbanizacyjnych. Są to miejsca gęsto zabudowane, podzielone na szersze i węższe uliczki, niemal całkowicie pozbawione zieleni. To one w najściślejszym znaczeniu zasługują na miano nekropolii - miasta umarłych. Obecnie określenie "nekropolia” zyskało inny wydźwięk, używa się go w odniesieniu do wielkich cmentarzy o znaczeniu kulturowym, takich jak Powązki i Łyczaków.

Zewnętrzną infrastrukturę cmentarza tworzą kaplice, grobowce, mogiły ziemne z krzyżami, pomniki, często centralnie usytuowane oznaki wyznaniowe (np. krzyż). Ich układ zawsze wyraża logicznie uzasadniony porządek, jest zatem nośnikiem informacji. Pomnik grobowy wyznacza granicę między dwoma światami - żywych i umarłych.

W sensie obiektywnym wszystkie inne miejsca na cmentarzu są jednakowo ważne, jednak kąt cmentarza i miejsca przy samym murze w dawnym, hierarchicznym, zróżnicowaniu poszczególnych elementów przestrzeni cmentarnej były nacechowane ujemnie. Ważną rolę w przestrzennej organizacji cmentarza odgrywa jego ogrodzenie. Jego symboliczna rola polega na wyznaczaniu granicy między sfefami sacrum i profanum. Osobne znaczenie ma brama cmentarna. Przejście przez nią jest ilustracją przekroczenia granicy między światem żywych i umarłych. Istotną funkcję pełnią także drogi prowadzące przez cmentarz, zwłaszcza główna z nich, wiodąca od bramy do centralnego punktu. Od połowy XIX wieku zaczęto określać ją mianem Alei Zasłużonych. Często umieszczone przy niej groby mają ważne znaczenie publiczne i legitymizują przyjętą lub głoszoną hierarchię wartości. Niezwykły, sakralny charakter drogi polega też na tym, że jest ona „ostatnią drogą” zmarłego podczas jego wędrówki w zaświaty.

Cmentarz jest przestrzenią o niezwykle silnym nacechowaniu znaczeniowym. Systemami znaków są elementy infrastruktury, na którą składają się:

- formy architektoniczne (grobowce);

- plastyczne (rzeźby, malowidła);

- językowo-literackie (epitafia) ${ }^{11}$.

Zjawiska te występują łącznie, wchodzą z sobą w liczne związki i wzajemnie uzupełniają znaczenia. Symboliczna funkcja roślinności została niemal całkowicie zapomniana, choć ona również miała swój udział w budowaniu znaczeń.

Antologia wierszy nagrobnych dowodzi świetnej przeszłości owego zjawiska literacko-kulturowego, wskazując jednocześnie na kryzys, który współcześnie dotknął

11 J. Kolbuszewski, op. cit., s. 77. 
tę dziedzinę ${ }^{12}$. Umieszczenie epitafium indywidualizowało człowieka. Wiersze nagrobne wiele mówiły o zmarłym, a jeszcze więcej o pomysłodawcach umieszczenia go na grobie. Inskrypcje nagrobne odsłaniały różnorakie zjawiska literackie, kulturowe, socjologiczne, będąc ważnym wyrazem reagowania na fakt śmierci.

W ciągu ostatnich lat praktyki pogrzebowe bardzo się zmieniły. Obecnie mamy do czynienia ze zunifikowanym stylem umierania (głównie w szpitalach czy hospicjach). Ludzie coraz rzadziej są świadkami konania i śmierci. Pewne tradycyjne zachowania, obecne w społecznościach wiejskich jeszcze 20-30 lat temu, dzisiaj nie mają się gdzie realizować. Do szpitala czy chłodni nie przychodzi się na „wspominki”. W drugiej połowie XX wieku istniały wyraźnie zarysowane różnice w rytuale pogrzebu osoby młodej, dziecka, dziewczyny, chłopaka, kobiety, mężatki, babci, gospodyni itp.

Obecnie równolegle do procesu ujednolicania rytuału pogrzebu następuje proces unifikacji cmentarzy. Rozwijający się przemysł wytwórczości sepulkralnej kreuje wzory i mody. Na cmentarzach nie mamy do czynienia ze śmiercią oswojoną i piękną ${ }^{13}$. Powielana przez zakłady kamieniarskie oszczędna ekspresja mogił nie czyni z nich świadectwa śmierci opłakiwanej. Współczesne niemówienie o śmierci ani jej nie oswaja, ani nie unicestwia. Śmierć przeraża dzisiaj jeszcze bardziej, gdyż zastaje człowieka nieprzygotowanego na nią. Podziwiamy filozofię życia i śmierci wcześniejszych epok, ponieważ wtedy w harmonijny sposób udawało się przenosić na cmentarze elementy światopoglądu ówczesnych ludzi ${ }^{14}$. Dzisiejszymi cmentarzami - ich wyglądem, estetyczną i filozoficzną treścią, formą ujmowania problematyki śmierci - rządzi skonwencjonalizowana cmentarna moda. Jest ona jedną z odmian współczesnej kultury popularnej i z nią przede wszystkim dzieli swoją estetykę, będącą często estetyką kiczu ${ }^{15}$. Wyglądem dzisiejszych cmentarzy rządzi dyktowana przez zakłady kamieniarskie, zajmujące się produkcją nagrobków, zunifikowana bezstylowość. Jednakowe tworzywo nagrobków, te same formy, ujednolicona, znacznie zredukowana symbolika. Wszystkie wymienione elementy składają się na „kryzys śmierci”, który można dostrzec także w zmianach zachodzących na cmentarzach ${ }^{16}$.

12 J. Kolbuszewski, Co mnie dzisiaj, jutro Tobie. Polskie wiersze nagrobne, Wrocław 1996.

13 P. Aries, Pięć wariacji na cztery tematy, [w:] Antropologia śmierci. Myśl francuska, wyb. i tłum. S. Cichowicz, J.M. Godzimirski, Warszawa 1993.

14 P. Aries, Człowiek i śmierć, przeł. E. Bąkowska, Warszawa 2011.

15 J. Kolbuszewski, Kicz w przestrzeniach śmierci, [w:] Problemy współczesnej tanatologii, t. 15, Wrocław 2011.

${ }^{16}$ J. Kolbuszewski, Kryzys, pornografia i renesans śmierci, [w:] Problemy wspótczesnej tanatologii, t. 1, Wrocław 1997. 


\section{Zmiany w wyglądzie cmentarzy}

W czasach, które pamiętają najstarsze respondentki, mieszkańcy wsi nie mogli sobie pozwolić na kamienne nagrobki, powszechnie stawiano drewniany krzyż i obramowanie wypełnione ziemią. Najbogatsze rodziny stawiały na grobach swoich zmarłych kuty krzyż, pomniki były wyjątkiem. Ziemne groby zazwyczaj zarastały chwastami i wysoką trawą, ponieważ na cmentarz chodziło się tylko raz do roku, z okazji Wszystkich Świętych. Często wraz z upływem lat zapominano, gdzie dokładnie leży dana osoba. Cmentarz był wspólną dla całej społeczności przestrzenią sakralizacji śmierci. Pogrzeb, jako jeden z rytuałów przejścia ${ }^{17}$, był najważniejszym momentem pożegnania zmarłego, troska o jego konkretny grób była sprawą drugorzędną. Cmentarze były

bardzo zaniedbane, jak poszli na Wszystkich Świętych to następny raz to dopiero za rok. Ludzie nie dbali o to, nie myśleli o tym tak jak teraz (R. 3).

Jedna $\mathrm{z}$ respondentek tak wspomina odwiedziny sprzed kilku lat w miejscowości rodzinnej (Polska centralna):

Jak były postawione znicze na Wszystkich Świętych, to jak w sierpniu tam pojechałam, to dalej stały (R. 1).

Najstarsze panie bardzo niechętnie opowiadały o tym, jak kiedyś opiekowano się cmentarzami, wręcz wstydziły się tego podejścia sprzed lat. Jednocześnie pamięć o przodkach była obecna w opowieściach rodzinnych, jednak niekoniecznie wiązało się to z podejmowaniem czynności porządkowych na grobach.

Wszystkie seniorki zgodnie podkreślały wielką pozytywną zmianę, jaka zaszła na tym polu.

Tak jak przedtem nie dbali, tak teraz bardzo się dba, jest pięknie na cmentarzu. Teraz tutaj dba się o cmentarze (R. 2).

Odpowiedzi mogą świadczyć o tym, że na ziemiach zachodnich szybciej zapanowały zwyczaje opieki nad grobami, częstszego ich odwiedzania i robienia porządków.

Lata pięćdziesiąte i sześćdziesiąte to okres stopniowego przekształcania grobów, oprócz grobów ziemnych coraz częściej zaczęly się pojawiać groby kamienne. Jednym z powodów tej zmiany jest lokalizacja - zmarłych ze Smardzowa chowano na cmentarzu komunalnym w Oleśnicy.

Powszechną akceptacją cieszą się kamienne groby:

kiedyś takich nie było, ale dobrze, że takie powstają, ponieważ tak te chwasty nie zarastają (R. 1).

Oprócz znaczącej zmiany wizualnej cmentarzy powstała klasyfikacja ważności zmarłych według wartości nagrobku. Ten proces szczególnej siły nabrał w ciągu ostatnich lat.

17 C. Herriger, Komunikacja bez słów. Rytuały społeczne, przeł. A. Szarypo, Wrocław 1997. 
Panie w średnim wieku w swoich opowieściach nie przedstawiają cmentarzy jako obszaru zaniedbanego czy też zarośniętego trawą. Z odpowiedzi wynika, że w okresie ich dzieciństwa cmentarze składały się w większości z grobów kamiennych. Opowiadając o czasach współczesnych, mówią, że

na cmentarzach to wręcz takie hangary się stawia i to wcale nie musi być grobowiec rodzinny tylko np. dla dwóch osób, ludzie wystawiają jeden naprzeciw drugiego (R. 6).

W sytuacji konieczności postawienia pomnika kwestią o mniejszym znaczeniu jest to, jakim człowiekiem był zmarły, najważniejsze są możliwości finansowe rodziny, jeśli jest ona zamożna, stara się wystawić „bardzo drogi pomnik” (R. 7). Respondentki jasno wyrażają pogląd, że im droższy kamień, z jakiego ma być przygotowany nagrobek, lub niewykorzystywane do tej pory na danym cmentarzu motywy - kształt grobu, kolorystyka czy elementy dodatkowe, tym lepszy odbiór zachowań rodziny przez pozostałych członków społeczności wiejskiej. Status społeczno-ekonomiczny danej rodziny jest potwierdzony.

Również w wypowiedziach najmłodszych respondentek pojawia się kwestia wielkości pomnika:

Często jak ktoś jest bogaty to wywala ten pomnik duży nie dla zmarłego, ale dla ludzi, mówi to nam o tym, że ludzie robią to na pokaz (R. 12).

Kwestie finansowe związane z budową pomnika są bardzo wyraźnie obecne w odpowiedziach respondentek. Osoby o słabszej sytuacji ekonomicznej również podejmują kroki (w ramach swoich możliwości), aby zapewnić sobie odpowiedni nagrobek. Respondentka relacjonuje:

jeśli tylko ktoś coś zmienia na pomniku, to ta pani, która ma skromną rentę i naprawdę nieraz ciężko jej dotrwać do emerytury, potrafi w roku zmienić trzy razy coś na nagrobku, na lepszy, zawsze na lepszy, żeby był jeszcze lepszy i na to jej nie żal pieniędzy, jednocześnie, co ciekawe, 20 lat temu to jej nie przeszkadzało, że nagrobka nie było (R. 10).

W relacji widać wyraźnie, jak bardzo zmieniła się mentalność mieszkańców wsi; kwestia, która 20 lat temu była praktycznie nieistotne, obecnie staje się jedną z kluczowych decyzji, jakie podejmuje się w życiu. Pomnik na cmentarzu, oprócz wielu zadań, jakie pełni, staje się wyraźną informacją odnośnie do zamożności rodziny.

Dla najmłodszego pokolenia cmentarze to zbiór różniących się wielkością, kształtem i kolorem kamiennych grobów.

Wszystkie pomniki są takie same, kamienne, średnio mi się to podoba (R. 11).

Na pytanie o powód powstawania takich grobów wszystkie respondentki odpowiadają podobnie - ten rodzaj wymaga mniejszej troski, jest łatwy w utrzymaniu,

nie trzeba go podlewać, poza tym, woda umyje taki grób, popada śnieg i nie widać aż tak bardzo brudu (R. 9). 
Można podać wiele powodów wpływających na mniejszą ilość żywych kwiatów i roślin obecnych na grobach. Najczęściej wskazuje się brak czasu i problemy z dojazdem do Oleśnicy. Często również nie ma miejsca na zieleń cmentarną:

Powycinali drzewa na starym cmentarzu w Oleśnicy, bo przeszkadzały ludziom i podobno groby podnosiły i zrobiła się kamienna pustynia (R. 12).

W społeczności wiejskiej ocenie podlega zarówno zachowanie rodziny na pogrzebie, jak i to, jak szybko i jaki pomnik najbliżsi wystawią swojemu zmarłemu.

Ludzie zastanawiają się, ciekawe jaki pomnik będzie miał (R. 6).

Warto odnotować też pewną rozbieżność:

Rodzina postawi piękny pomnik, trzy razy do roku zmieniają stroik, ale kiedy przychodzi pogrzeb, nie potrafią się zachować (R. 8).

Sankcje wynikające z niewłaściwego zachowania osób na pogrzebie nie są tak odczuwalne, jak kiedyś, ale nadal w wypowiedziach respondentek można dokonać wyraźnego podziału na osoby, rodziny, które potrafią się godnie i właściwie zachować w danej sytuacji, oraz takie, które zachowują się niewłaściwie.

Kolejną ważną zmianą zachodzącą w wyglądzie cmentarzy jest powstawanie grobów rodzinnych. Zjawisko to wcześniej nie było znane w społecznościach wiejskich. Najstarsze mieszkanki Smardzowa nie pamiętają, aby w ich miejscowościach były groby rodzinne. Takie praktyki były typowe dla mieszkańców miast, przedstawicieli mieszczaństwa i ziemiaństwa. Obecnie zjawisko to jest powszechnie oceniane jako pozytywne:

Fajnie, że rodzina się trzyma razem nawet po śmierci (R. 10).

Często przytacza się aspekt ekonomiczny:

Niewątpliwie grobowce rodzinne mają znaczenie praktyczne, wszyscy leżą razem i można się w jednym miejscu opiekować grobem, dlatego też ludzie zadają sobie trud sprowadzania ciała z miejsc, gdzie człowiek był pochowany, byle tylko mieć zmarłych blisko siebie (R. 11).

Grobowce rodzinne, bycie blisko z najbliższymi nawet po śmieci, zawsze robi na mnie duże wrażenie, pokazuje to siłę rodziny (R. 7).

Troska o miejsce pochówku wyraża się także w kupowaniu wcześniej, przed śmiercią, miejsca na cmentarzu.

Na niektórych cmentarzach jest mało miejsca a np. mąż i żona chcą leżeć obok siebie i wtedy to jest bardzo zasadne działanie. Wcześniej tak nie było (R. 3).

Chcąc uniknąć problematycznych sytuacji, część osób myśli o tych kwestiach zawczasu, o tym, żeby później nie było kłopotu z tym, gdzie kolejną osobę pochować (R. 4).

To podejście ma też bardziej kontrowersyjne oblicze, dwie respondentki zwróciły uwagę, że 
jest przesadą wykuwanie sobie imienia nazwiska i daty urodzenia i przychodzenie na swój własny grób, a zdarzają się takie osoby, że tylko daty śmierci brakuje, tak jakby one już czekały na śmierć (R. 6).

Wykupywanie miejsca na cmentarzu pośrednio wiąże się to z tym, że

nikt nie chce być pochowany obok śmieci i w rogu cmentarza (R. 3).

Kilkukrotnie pojawia się odpowiedź „leżeć pod płotem” (R. 1, R. 2, R. 4), która jednoznacznie wskazuje na niski status społeczny rodziny osoby pochowanej, której nie było stać na zapewnienie godnego miejsca na cmentarzu i zmarły „wylądował pod płotem" (R. 2). Waloryzowanie poszczególnych przestrzeni na cmentarzu jest silnie obecne w wypowiedziach najstarszych osób:

Najlepiej leżeć gdzieś blisko kaplicy lub w ładnej alei (R .4).

Inne stanowiska przedstawiają osoby najmłodsze:

Lepsze i gorsze miejsca, kiedyś podobno istniał taki podział, ale wg mnie już go nie ma, chociaż istnieją lepsze lub gorsze groby, ale jeśli chodzi o topografię, to nie ma już to znaczenia (R. 10).

Niemal we wszystkich wywiadach pada stwierdzenie, że „miejsce pod płotem jest gorsze". Jednocześnie

jak nie ma miejsca, to nawet pod siatką na ładnym cmentarzu jest dobre miejsce (R. 11).

$\mathrm{Na}$ tablicy nagrobnej umieszcza się imię, nazwisko, datę urodzin, datę śmierci. W ciągu wielu lat pojawiały się różnorodne obyczaje dotyczące umieszczania epitafiów. Według najstarszych mieszkanek dawniej epitafiów w ogóle nie było, dopiero wraz z nastaniem pomników kamiennych zaczęły się pojawiać napisy, najczęściej wymieniane były:

Spoczywaj w pokoju, Prosi o Zdrowaś Mario, Prosi o modlitwę (R. 1, R. 2, R. 3, R. 4, R. 5, R. 6 , R. 7, R. 8, R.9, R. 10, R. 11, R. 12).

Według średniego pokolenia bardzo popularne przez pewnie okres było sformułowanie

Tu leży najukochańszy mąż, tatuś i dziadziuś (R. 1, R. 2, R. 3, R. 4, R. 6, R. 7, R. 8).

Niewątpliwie wielu zmarłych zasłużyło sobie na taki napis, ale niekiedy słowa stoją w sprzeczności z zachowaniem danej osoby:

Po sądach się ciągali, mąż ją bił, do domu kochanki sprowadzał, a potem „najukochańszy”, papier czy kamień wszystko przyjmie (R. 6).

Ludzie na wsi znają się nawzajem, przechodząc koło takiego grobu, mogą mieć co najmniej „mieszane odczucia” (R. 6).

Jeśli na grobie pojawiało się epitafium, zmarłego postrzegano przede wszystkim w rolach rodzinnych — jako męża, ojca i dziadka. Szczególnym przypadkiem wymienianym przez respondentki było umieszczanie epitafium na grobach dzieci, na przykład 
Powiększył grono aniołów (R. 7).

Jedna respondentka w średnim wieku jako przykład znanego epitafium, z którym się spotkała, przytoczyła fragment wiersza ks. Jana Twardowskiego:

Spieszmy się kochać ludzi, tak szybko odchodzą (R. 8).

Do namysłu skłaniają epitafia w stylu:

Przechodniu nie martw się mną, ale zajmij się sobą, ty też tu będziesz niedługo leżał. Są one bardzo sugestywne (R. 9).

Najmłodsza respondentka wymieniła epitafium:

W niebie Boga oglądać będzie.

Jak stwierdziła, to zdanie

daje nadzieję, weź się grzeszniku za siebie, my tu leżący i wy żywi będziemy oglądać w niebie Boga, tak czy tak po śmierci będziesz oglądać Boga, a czy zostaniesz w niebie to już Twoja sprawa, to ma głębszy sens. Jest to bardzo oryginalne epitafium na cały stary cmentarz w Oleśnicy (R. 12).

Obecnie dąży się do zmniejszania kosztów finansowych (każda litera mająca znaleźć się na grobie to dodatkowa opłata); epitafia pojawiają się coraz rzadziej, nie indywidualizują poszczególnych osób, nie dostarczają wiadomości na temat tego, kim był zmarły. Dodatkowe informacje o zmarłym, jeśli rodzina sobie tego życzy, występują na klepsydrach. Zanik epitafiów na pewno sprawia, że cmentarz jako tekst kultury jest uboższy. Można zaryzykować stwierdzenie, że współczesnym ludziom taka forma poetycka jest coraz mniej potrzebna i nie przyczynia się do oswojenia z myślą o śmierci. Jednocześnie epitafia, które są obecne na grobach, przyciągają wzrok, zapadają w pamięć i stają się przyczynkiem do mniej lub bardziej świadomych rozważań na temat tego, dlaczego się tam pojawiły oraz tego, co nas czeka po śmierci.

W ciągu ostatnich kilkudziesięciu lat wygląd cmentarzy bardzo się zmienił. Na pytania o dość trudno definiowalną modę cmentarną pojawiały się odpowiedzi, w których modę rozumiano jako popularność pewnych elementów na cmentarzu. Jednym z nich, wskazanym przez seniorki, było umieszczanie napisu

Tu leży najukochańszy mąż (R. 1, R. 2, R. 3, R. 4, R. 6, R. 7, R. 8),

czego obecnie się już prawie nie robi. Pani w średnim wieku zaproponowała swoje rozumienie mody cmentarnej, jest to

fason pomnika, kamień, z jakiego jest zrobiony, czarny, grafitowy itp., ozdoby dodatkowe, flakony, to, czy ciało jest poddane kremacji, czy nie, urny kolor, kształt, wielkość, plastikowe wieńce, lub kwiaty żywe, płaczące aniołki, plastikowe świece, figurki Matki Boskiej, furtki i ogrodzenia grobów lub ich brak (R. 8).

Wszystkie te elementy zmieniają się, raz są popularne, innym razem już nie.

Wiele miejsca w swoich odpowiedziach respondentki poświęcają dekoracjom grobów. Wskazuje się, że zadbany grób to taki, na którym regularnie pojawiają się 
„stroiki, kompozycje kwiatowe” (R. 1, R. 2, R. 3, R. 4, R. 6, R. 7, R. 8). Najczęstszym materiałem, z którego są wykonane, są sztuczne, wielobarwne kwiaty i dodatki florystyczne.

Zadbany grób to taki gdzie na Wszystkich Świętych jest nowy ładny stroik (R. 5)

— relacjonuje jedna $\mathrm{z}$ respondentek w średnim wieku.

Żywe chryzantemy też są przepiękne, ale niestety pierwszy przymrozek i już są klapnięte, a taki stroik to postoi i zdobi (R. 6).

Kwestia dodatkowego ogrodzenia grobu jest podejmowana przez wszystkie panie w średnim wieku, dodatkowo jedna z najmłodszych respondentek stwierdza:

Jak było ogrodzenie, to był jasno wyznaczony teren zmarłego, była zaznaczona prywatność tego zmarłego, a teraz wszyscy leżą obok siebie, zmarłemu należy się teren i przestrzeń, a nie żeby obcy ludzie chodzili po ziemi, tam gdzie jest się pochowanym. Ludzie wtedy nie mogli chodzić między grobami, na skróty tylko po ścieżkach (R. 11).

Różnice w wyglądzie grobów to przejaw mody cmentarnej. Jacek Kolbuszewski bardzo negatywnie ocenia współczesną „modę cmentarną, zarzucając je mierność, brak umiejętności przekazania światopoglądu współczesnego człowieka na temat życia i śmierci ${ }^{18}$. Najstarsze mieszkanki Smardzowa są bardzo zadowolone z obecnego wyglądu cmentarzy, z zainteresowania tym, aby pomnik był estetyczny i zadbany:

Ludzie aż się prześcigają w nowinkach, aż to wszystko oczy cieszy, jak niektórzy ludzie dbają (R. 4).

Nie wszystkie panie ze średniego pokolenia podzielają entuzjazm seniorek:

Można mówić nawet o pewnej „jarmarczności” na cmentarzach, im pomnik bardziej kolorowy, większy, ma więcej złotych liter, to już nie skłania do refleksji, ale wręcz śmieszy (R. 8).

Nie zyskują również akceptacji pewne nowe

wizje artystyczne, kto to widział, aby na krzyżu różę umieszczać, na krzyżu umarł Pan Jezus i niech on tam sobie wisi, a nie róża (R. 6).

\section{Obecność na cmentarzu}

W porównaniu do czasów młodości najstarszych mieszkanek Smardzowa, gdy przebywały w innych częściach Polski, obecnie znacznie częściej chodzi się na cmentarze. Wskazuje się utrudnienia komunikacyjne, ale według respondentek na grobach obowiązkowo należy być na Wszystkich Świętych i w okolicach Bożego Narodzenia:

18 J. Kolbuszewski, Kryzys, pornografia... 
Nie zawsze można w ten dzień, ale można w np. w drugi dzień świąt (R. 1, R. 6, R. 7, R. 8)

oraz na Wielkanoc. Oprócz tego dobrze jest pamiętać o rocznicy śmierci oraz imieninach lub urodzinach zmarłego. Starsze osoby podkreślają, że chciałyby dużo częściej odwiedzać cmentarze, ale jest to uzależnione od wielu czynników. Rodzina nie zawsze jest chętna do wyjazdu samochodem, jednocześnie koszt dojazdu autobusem do Oleśnicy jest zbyt wysoki.

Bardzo podobne, jeśli chodzi o obecność na cmentarzu, są wypowiedzi pań w średnim wieku oraz najmłodszych respondentek:

Na święta na cmentarz trzeba iść, bo nie wypada inaczej się zachować (R. 12).

Data imienin lub urodzin nieboszczyka oraz data śmieci zobowiązują najbliższych do odwiedzenia cmentarza. Częstsze odwiedzanie grobów jest już indywidualną sprawą, na przykład jedna $\mathrm{z}$ najmłodszych respondentek deklarowała wizyty na cmentarzu dwa razy w tygodniu w celu podlewania kwiatów, jednak wydaje się, że jest to wyjątek. Częstość odwiedzania grobów najbliższych zależy też od czasu, który minął od ich śmierci.

Tradycją jest już spotykanie się $\mathrm{w}$ dużym gronie rodziny na cmentarzu w pierwszych dniach listopada:

$\mathrm{Na}$ cmentarzu spotykam rodzinę tę bliższą i dalszą, rozmawiamy, często też spotykam znajomych. (R. 10).

Można zaryzykować stwierdzenie, że dzień Wszystkich Świętych przejął część funkcji, które przedtem odgrywało Boże Narodzenie. W miejscu publicznym, jakim jest cmentarz, bez wnoszenia znacznych kosztów, raz do roku istnieje duża szansa na spotkanie się w szerszym gronie rodzinnym. Kulminacyjnym punktem

świąt listopadowych jest procesja, jaka ma miejsce na starym cmentarzu w Oleśnicy, co roku odbywająca się o godz. 16 i niezmiennie przyciągająca tłumy ludzi (R. 8).

Wszystkie respondentki wskazywały, że będąc na cmentarzu, najczęściej modlą się w intencji zmarłych, proszą o ich pomoc i wstawiennictwo w danej sprawie, następnie sprzątają groby, wynoszą liście, przynoszą wodę do podlania, jeśli jest taka konieczność, zapalają świece. Płomień świecy ma różnorakie znaczenia, według seniorek symbolizuje

pamięć, światłość, płomień to rodzaj nadziei, że ta dusza jest jednak gdzieś w zaświatach (R. 4).

Panie w średnim pokoleniu deklarowały, że

taki płomyczek ożywia cały nagrobek, zaraz się coś dzieje, grób staje się weselszy, jak ten płomyczek pali się w lampionie (R. 5).

Najmłodsze respondentki uważają, że zapalenie świeczki oznacza

światło, nadzieję, wieczność, nieśmiertelność, światełko w ciemności, oczyszczenie, niech im świeci światło, nie zapomina się tych, którzy odeszli przed nami (R. 9). 
Istnieje pewna kolejność odwiedzania grobów; z wypowiedzi badanych wynika, że na początku zawsze odwiedza się najbliższą rodzinę, następnie sąsiadów, znajomych, którzy leżą na tym samym cmentarzu. Świece zapala się za każdym razem, będąc na cmentarzu:

Wtedy świecę u rodziny a w czasie świąt listopadowych, kiedy odwiedzam wszystkie groby znajomych, to zapalam świeczki wszędzie, a na koniec idę na cmentarz żołnierzy radzieckich i tam też świecę (R. 8).

Odwiedzanie grobów sąsiadów, chwila modlitwa, zapalenie świecy są elementem pamięci danej osoby o zmarłym.

Kolejną interesującą kwestią była odpowiedzialność za porządek na grobach. Najczęściej obowiązki te spoczywają na osobie, która "została w domu” (R. 8), mieszkała z rodzicami do śmierci, „dostała w spadku gospodarkę" (R. 1), często zdarza się, że dana osoba "najbardziej się poczuwa” (R. 6) i sama angażuje się w opiekę nad grobami. W dwóch wypowiedziach podkreślono fakt, że nieraz wkłada się dużo wysiłku, aby ciało sprowadzić $\mathrm{z}$ dalekich stron, byle tylko nie musieć się martwić tym, kto będzie opiekował się grobem.

Równocześnie w odpowiedziach pojawiają się opisy sytuacji, gdy rodzina niechętnie lub w ogóle nie angażuje się w opiekę nad grobami swoich najbliższych. Takie zachowania zostały bardzo negatywnie ocenione przez respondentki. Podejmowanie czynności porządkowych na grobach może być efektem presji środowiska społecznego, w którym jednostka żyje i funkcjonuje. Szczególnie mocno jest to widoczne w miejscowościach, w których upowszechnił się wzór sprawowania szczególnej pieczy nad grobami.

W ciągu lat pojawiają się „znajomości cmentarne” (R. 8), sąsiedztwo grobów sprawia, że osoby, które się nimi opiekują, najpierw się z sobą zapoznają, następnie jedna strona może pomóc drugiej w opiece nad grobem na przykład „przy walce z chwastami" (R. 8).

Wystawienie pomnika, a następnie troska o grób są wskaźnikami zaangażowania rodziny, czynności te są odnotowywane przez sąsiadów, krewnych i wchodzą w skład oceny rodziny zmarłego.

\section{Kwestia cmentarza w Smardzowie}

W Smardzowie znajduje się poniemiecki cmentarz. Najstarsze panie wspominają, jak wyglądał jeszcze w latach pięćdziesiątych i sześćdziesiątych:

Znajdowały się tam przepiękne grobowce, duże, marmurowe, otoczone kutymi ogrodzeniami z furteczką, były również groby skromniejsze, obwódka była kamienna i rosły przepiękne kwiaty (R. 4).

Respondentka w średnim wieku wspomina: 
Pierwszy raz widziałam tam żółte żonkile, były też przebiśniegi. Tam gdzie rośnie obecnie bez, był olbrzymi czarny marmurowy grobowiec, obok rosła różowa, pnąca róża, zestawienie dawało piorunujący efekt, napisy wykonane były literami stylizowanymi na gotyckie (R. 8).

Na skutek wandalizmu

większość nagrobków zostało rozkradzionych, zaczęły powstawać zakłady kamieniarskie, a poza tym przyjeżdżali Niemcy i pożyczali w szkole łopaty, chodzili na ten cmentarz kopać, i poszła po wiosce fama, że Niemcy zostawili tam nie wiadomo jakie majątki, niestety Polacy w poszukiwaniu skarbów cmentarz rozkopali cały, nie umieli uszanować żadnej świętości (R. 8).

Wraz z postawieniem w latach osiemdziesiątych plebanii w Smardzowie

ksiądz proboszcz chciał zaadaptować ten cmentarz dla potrzeb wioski, ale w gminie okazało się, że ten cmentarz jest opłacony do przodu na wiele lat i nie wolno go ruszyć (R. 6).

Cmentarz stopniowo popadł w zapomnienie, obecnie cały jego obszar porośnięty jest drzewami i krzewami.

Poniemiecki cmentarz jest traktowy jako ciekawostka $\mathrm{w}$ krajobrazie wsi. Jedna z najmłodszych respondentek wysunęła nawet propozycję tego, aby

w jakiś sposób uczcić tych ludzi, którzy zostali tam pochowani, np. z obecnych tam jeszcze fragmentów porozbijanych płyt nagrobnych stworzyć pomnik. Cmentarz powinien być uporządkowany, ponieważ teraz stoi w zapomnieniu (R. 9).

Głos ten jest raczej odosobniony, nie ma odpowiedniej osoby, która chciałby się zająć uporządkowaniem tej sprawy.

Przed drugą wojną światową w Smardzowie funkcjonował cmentarz, nie było budynku kościoła. W latach osiemdziesiątych w ramach czynu społecznego w budowano kaplicę, filię parafii w Oleśnicy. Obecnie budynek kaplicy wchodzi w skład parafii Borowa Oleśnicka z siedzibą plebanii w Smardzowie. Respondentki zostały zapytane o ewentualne powstanie cmentarza dla obecnych mieszkańców Smardzowa. Kwestia ta okazało się dość kontrowersyjna, opinie były podzielone.

Najstarsze panie, które twierdziły, że należy założyć cmentarz w Smardzowie, jako główny powód przytaczały problemy komunikacyjne:

Wydać 6 zł na autobus, a potem jeszcze kawał iść to starsi ludzie nie mają pieniędzy i nie mogą iść. Lepiej by było tu na miejscu świeczkę kupić, pójść i zapalić (R. 3).

Kolejny ważny powód to mobilizacja do większej troski o groby:

gdyby cmentarz był na miejscu, to groby by były bardziej zadbane, na pewno każdy by częściej poszedł, w niedzielę pomodlić się, odwiedzić swoich zmarłych, a tak to ciężko co tydzień prosić: może pojedziemy do Oleśnicy na cmentarz. Po za tym byłaby motywacja, żeby dbać o groby. A tak groby leżą sobie w mieście, anonimowo i ludzie myślą: w natłoku jakoś będzie (R. 2).

Jedną z przyczyn, dla których w Smardzowie nie zapadła decyzja o utworzeniu cmentarza, był fakt, że zaraz po wojnie wioska należała do parafii Oleśnica, tam jeżdżono na msze, tam również chowano zmarłych. $Z$ wypowiedzi respondentek 
można skonstruować schemat zachowań. Obecnie trudno by było zmieniać te przyzwyczajenia.

Wśród seniorek pojawiły się również argumenty przeciw założeniu cmentarza:

Rodzina musiałaby i tak do Oleśnicy jechać, nawet jakby był cmentarz w Smardzowie. Trzeba było od razu założyć, jak tu przyjechali. Każda rodzina stara się na jednym cmentarzu mieć bliskich, i już do przodu kupuje się miejsca, odkupuje, nawet nieraz przepłaca tak, żeby mieć groby na jednym cmentarzu. Jest jednak jakaś „tęsknota”, że chciałoby się ze swoimi, na jednym cmentarzu, blisko (R. 1).

Ten fragment wyraźnie wskazuje chęć bycia pochowanym w jednym miejscu $\mathrm{z}$ bliskimi, tak aby w miarę możliwości uniknąć problemów z przemieszczaniem się z jednego cmentarza na drugi.

Opinie pań w średnim wieku, dotyczące kwestii założenia cmentarza, są podzielone, oprócz argumentów wymienionych przez seniorki dochodzi kwestia jego lokalizacji.

Wokół kościoła jest zbyt mało miejsca i trzeba by było wyznaczyć jakiś nowy teren (R. 5).

Jedna z respondentek podkreśliła możliwość ekshumacji. Wtedy nie występowałby problem jeżdżenia do Oleśnicy.

Można dokonać ekshumacji tych najbliższych i przenieść do Smardzowa, wtedy można być na cmentarzu nawet codziennie, a przynajmniej raz w tygodniu. I wtedy mogłoby być na grobach więcej roślin, każdy byłby je w stanie podlać. W mieście jest to niemożliwe, nie każdego jest stać jechać i podlewać lub wymieniać świeżo ścięte kwiaty. Jak się takie wstawi to 2 lub 3 dni i ugotowane. Jeśli stoją takie brzydkie, oklapłe kwiaty, to one nie dekorują, tylko szpecą grób. I świadczą o tym, że rodzina nie dba o grób, nie pamięta o zmarłym (R. 9).

Najmłodsze pokolenie wskazywało, że z jednej strony cmentarz w Smardzowie to bardzo dobry pomysł, ponieważ

na pewno umocniłoby to wioskę jako całość, ludzie by się częściej spotykali (R. 11).

Nie byłoby problemu, gdzie na przykład pochować rodziców:

Mama chce ze swoimi rodzicami a tata ze swoimi, no i jest problem.

$\mathrm{Z}$ drugiej strony

większość osób ze Smardzowa jest pochowana w Oleśnicy, więc trudno by pewnie było komuś pierwszemu zdecydować się na to, żeby zostać pochowanym w Smardzowie (R. 12).

\section{Podsumowanie}

Na podstawie przeprowadzonych badań można wskazać zmiany, jakie zaszły w funkcjonowaniu cmentarzy w ciągu ostatnich kilkudziesięciu lat. Nastąpiły istotne modyfikacje w materiale budulcowym nagrobków, w ich zewnętrznym wyglądzie i stylistyce. Warto podkreślić tendencje do coraz bardziej zindywidualizowanego zapamiętywania zmarłych; groby ziemne ustąpiły grobom kamiennym. 
Odeszło się od wspólnego wspominania wszystkich zmarłych z danej społeczności, których łączyła przestrzeń cmentarza. Ta zmiana może być wskazaniem stopniowej, systematycznej rezygnacji z życia wspólnotowego, na którym kiedyś zasadzało się funkcjonowanie wiejskich społeczności w kulturze chłopskiej.

Przestrzeń cmentarza jest nadal różnorodnie waloryzowana. W wypowiedziach respondentek często podkreślane jest utrzymanie względnej bliskości grobów, w ten sposób dba się o zachowanie związków rodzinnych. Podobnie jak $\mathrm{w}$ życiu wsi, silne znaczenie dla utrzymywania pamięci o zmarłym ma przynależność rodzinna zmarłego. To, jaki pomnik się postawiło i jak się dba o groby swoich najbliższych, świadczy o całej rodzinie. Odnotowano znaczące zmiany w częstotliwości odwiedzania cmentarzy oraz w trosce o wygląd grobów.

Ostatnią kwestią przedstawioną $\mathrm{w}$ artykule były opinie respondentek na temat potrzeby założenia cmentarza w Smardzowie. Zdania na ten temat były bardzo podzielone, nie wydaje się zatem, aby w najbliższym czasie nastąpiły zmiany w tym zakresie.

\section{Bibliografia}

Aries P. Człowiek i śmierć, przeł. A. Szarypo, Warszawa 2011.

Aries P., Pięć wariacji na cztery tematy, [w:] Antropologia śmierci. Myśl francuska, wyb. i tłum. S. Cichowicz, J.M. Godzimirski, Warszawa 1993.

Helling I., Metoda badań biograficznych, [w:] Metoda biograficzna w socjologii, red. J. Włodarek, M. Ziółkowski, Warszawa 1990.

Herriger C., Komunikacja bez słów. Rytuały społeczne, przeł. E. Bąkowska, Wrocław 1997.

Jaszczak A., Dreksler B., Cmentarze - miejsca pamięci, tradycji i religii, [w:] Cmentarze i ogrody w krajobrazie. O sacrum, symbolice, kompozycji i przemijaniu, red. A. Zachariasz, Sosnowiec 2013.

Kolbuszewski J., Cmentarze, Wrocław 1996.

Kolbuszewski J., Co mnie dzisiaj, jutro Tobie. Polskie wiersze nagrobne, Wrocław 1996.

Kolbuszewski J., Kicz w przestrzeniach śmierci, [w:] Problemy wspótczesnej tanatologii, t. 15, Wrocław 2011.

Kolbuszewski J., Kryzys, pornografia i renesans śmierci, [w:] Problemy wspótczesnej tanatologii, t. 1, Wrocław 1997.

Olej-Kobus A., Kobus K., Rembas M., Nekropolie. Zabytkowe cmentarze wielokulturowej Polski, Warszawa 2009.

Przybyłowska I., Wywiad swobodny ze standaryzowana lista poszukiwanych informacji i możliwości jego zastosowania w badaniach socjologicznych, „Przegląd Socjologiczny” 30, 1978.

Sobczak A., Poradnik cmentarny. Kościelne i cywilne normy prawne o cmentarzach i chowaniu zmartych wraz $z$ orzecznictwem, Gniezno 2003.

Straczuk J., Cmentarz i stót, Toruń 2013.

Sulima R., Słowo i etos, Kraków 1992. 